\title{
Effects of Ethanolic Extract of the Leaves of Pongamia glabra and Gliricidia sepium against Rhipicephalus (Boophilus) annulatus
}

\section{Reghu Ravindran ${ }^{1 *}$, Sanis Juliet ${ }^{2}$, Sunil Athalathil Ramankutty ${ }^{1}$, Nanjundappa Sathish ${ }^{2}$, Suresh Narayanan Nair ${ }^{2}$, Karaparambu Gopalan Ajithkumar ${ }^{1}$, Leena Chandrasekhar ${ }^{3}$, SRIKANT GHOSH ${ }^{4}$}

\begin{abstract}
${ }^{1}$ Department of Veterinary Parasitology; ${ }^{2}$ Department of Veterinary Pharmacology and Toxicology; ${ }^{3}$ Department of Veterinary Anatomy, College of Veterinary and Animal Sciences, Pookode, Lakkidi, P.O. Wayanad, Kerala-673576, India; ${ }^{4}$ Division of Parasitology, Indian Veterinary Research Institute, Izatnagar, UP-243122, India.
\end{abstract}

\begin{abstract}
The effects of ethanolic extracts of the leaves of Pongamia glabra and Gliricidia sepium against Rhipicephalus (Boophilus) annulatus were studied. Different dilutions of the extracts such as 50, 60, 70, 80, 90 and $100 \mathrm{mg} / \mathrm{mL}$ were tested using adult immersion test (AIT). The per cent adult mortality, inhibition of fecundity and hatching of laid ova were studied. Both extracts caused very low per cent adult tick mortality and inhibition of fecundity. Fifty per cent blocking of the hatching of laid ova in ticks treated with ethanolic extract of leaves of P. glabra was observed.
\end{abstract}

\section{Keywords | Pongamia, Gliricidia, Rhipicephalus annulatus, Acaricidal}

Editor | Kuldeep Dhama, Indian Veterinary Research Institute, Uttar Pradesh, India.

Received | December 27, 2016; Accepted | January 01, 2017; Published | January 05, 2017

*Correspondence | Reghu Ravindran, Kerala Veterinary and Animal Sciences University, Pookode, Lakkidi, P.O. Wayanad, Wayanad, Kerala, India; Email: drreghuravi@yahoo.com

Citation | Ravindran R, Juliet S, Ramankutty SA, Sathish N, Nair SN, Ajithkumar KG, Chandrasekhar L, Ghosh S (2017). Effects of ethanolic extract of the leaves of Pongamia glabra and Gliricidia sepium against Rhipicephalus (Boophilus) annulatus. Adv. Anim. Vet. Sci. 5(1): 1-6.

DOI | http://dx.doi.org/10.14737/journal.aavs/2017/5.1.1.6

ISSN (Online) | 2307-8316; ISSN (Print) | 2309-3331

Copyright $(92017$ Ravindran et al. This is an open access article distributed under the Creative Commons Attribution License, which permits unrestricted use, distribution, and reproduction in any medium, provided the original work is properly cited.

\section{INTRODUCTION}

$\mathrm{T}$ ick control throughout the world is based mainly on the use of chemical acaricides. Their indiscriminate and repeated use has already resulted in problems related to environmental pollution, milk/meat contamination and the development of resistance in target species along with a subsequent increase in cost (Dipeolu and Ndungu, 1991; Jonsson and Piper, 2007). The use of extracts from various plants is being explored as an alternative to chemical acaricides because they are potentially less toxic to the animals and safer for the environment.

Pongamia glabra. Linn. (Papilionaceae) (Synonym; leaf gall, Pongamia pinnata) which may also be called as Galdupa indica, is a large tree found in tropical regions and coastal forests of India, North Australia, Southeast Asia and Malaysia (Krishnamurthy, 1969; Satyavati et al., 1987). Antiinflammatory and antidiarrhoeal (Singh and Pandey, 1996; Singh et al., 1996; Srinivasan et al., 2001), antidiarrhoeal
(Shoba and Thomas, 2001; Brijesh et al., 2006), antimalarial (Misra et al., 1991), antibacterial (Patel and Trivedi, 1962; Biswal et al., 2011), wound healing (Subramanian and Nagarajan, 1988), anticancer (Arulvasu et al., 2012), anthelmintic (Nirmal et al., 2007) and analgesic (Ganesh et al., 2008) activities of the plant were previously reported. Efficacy of oil of karanj against different mange conditions in animals (Chabbra et al., 1994; Das and Sreekrishanan, 1998; Kale and Panchegaonkar, 1969; Prajapatie and Hiregoudar, 1976) was previously reported. Bisen et al. (2011) observed 70 and 66.67 per cent efficacy for the karanj seed oil and leaf extract respectively against Rhipicephalus (Boophilus) microplus after 5 days of treatment.

Gliricidia sepium, is a leguminous tree belonging to the family Fabaceae is used as fuel wood, animal feed, green manure, shade, living fences and as a support plant (Csurhes and Edwards, 1998). Gliricidia, which literally means 'rat poison' originated in Central America and its plantations, has spread to many parts of the world specif- 
ically south Asia. The plant is used by the farmers to repel insects. Moreover, the antibacterial (Nazli et al., 2008) and anthelmintic (Adama et al., 2012) properties were also recorded. Ethanolic extract of leaves of G. sepium at 20 per cent concentration produced 100 per cent acaricidal effects against the mite Tetranychus cinnabarinus (Sivira et al., 2011). Soap made using G. sepium leaf extract (20 per cent) was effective in clearing mange conditions in dogs including demodicosis (Viste et al., 2013). Also, G. sepium extract produced $53.33 \%$ mortality against Rhipicephalus (Boophilus) microplus (Rodriguez and Pulido, 2015).

$R$. (B.) annulatus, one of the most important bovine one host tick species (Onofree et al., 2001), serves as the vector for the agents of animal as well as some human diseases. $R$. (B.) annulatus is the major one host tick species of southern India (Jagannath et al., 1979; Rajamohanan, 1982; Koshy et al., 1982). Present study focuses mainly on the effect of the ethanolic extract of the leaves of P. glabra and G. sepium against adult female $R$. (B.) annulatus.

\section{MATERIAL AND METHODS}

\section{Plant Material}

The leaves of P. glabra and G. sepium were collected from Kalpetta, Wayanad district, Kerala. The plants were identified by a botanist and the voucher specimens were deposited in the herbarium of the Department of Botany, Calicut University, Kerala (Accesssion no; P. glabra- CALI 6628, G. sepium- CALI 6643).

\section{Preparation of the Plant Extracts}

The leaves were cleaned and dried in shade at room temperature. Dried plant leaves were finely pulverized using a grinder. The powdered plant material $(100 \mathrm{~g})$ was used for ethanolic extraction in a soxhlet extraction apparatus attached with rotary vacuum evaporator (Butchi, Switzerland). Solvent was completely removed by drying at room temperature. Required quantity of the extracts was weighed and dissolved in 1 per cent Tween- 20 or water for making six different dilutions at the rate of $50 \mathrm{mg} / \mathrm{mL}, 60$ $\mathrm{mg} / \mathrm{mL}, 70 \mathrm{mg} / \mathrm{mL}, 80 \mathrm{mg} / \mathrm{mL}, 90 \mathrm{mg} / \mathrm{mL}$ and $100 \mathrm{mg} /$ $\mathrm{mL}$ and were used for acaricidal bioassay.

\section{Ticks}

Fully engorged adult female $R$. (B.) annulatus were collected from infested animals, washed with water and dried using tissue paper. These ticks were used for adult immersion test (AIT).

\section{Adult Immersion Test (AIT)}

Various dilutions $(50-100 \mathrm{mg} / \mathrm{mL})$ of ethanolic extracts of the leaves of the plants were tested using adult immersion test (Drummond et al., 1973). A total of 336 numbers of ticks were used for the experiment. Four replicates of six ticks were used for each dilution of the extract. Group of six numbers of ticks were weighed prior to the experiment and they were immersed for 2 minutes in the respective dilution $(10 \mathrm{~mL})$ in a $50 \mathrm{~mL}$ beaker with gentle agitation. Tween 20 (0.1\%) was used as control for P. glabra extract while water was used as control for G. sepium. Ticks were recovered from the solution, dried using tissue paper towels and placed in separate plastic specimen tube ( 25 X 50 $\mathrm{mm}$ ). The tubes were incubated at $28^{\circ} \mathrm{C}$ and $80 \%$ relative humidity in a BOD incubator.

\section{Adult Tick Mortality}

The specimen tubes were observed for the next 15 days for mortality and the per cent adult tick mortality was determined.

\section{InHibition of Fecundity ANd Hatching}

The eggs laid by the ticks of each tube were collected, weighed and observed at the same condition of incubation for the next 30 days for visual estimation of hatching. Ticks under different treatments were compared with that of the controls.

The percentage inhibition of fecundity was calculated as follows (FAO, 2004):

$$
\text { Index of egg laying (IE) }=\frac{\text { Weight of eggs laid }(\mathrm{mg})}{\text { Weight of females }(\mathrm{mg})}
$$

$\%$ inhibition of fecundity (IF) $=\frac{\text { IE (control group) }- \text { IE (treated group) }}{\text { IE (control group) }} \times 100$

\section{Statistical Analysis}

Data were expressed as the mean \pm SEM. Groups were compared using one-way ANOVA for repeated measurements using SPSS software. Duncan's test was used for post-hoc analysis. A value of $\mathrm{P}<0.05$ was considered significant.

\section{RESULTS AND DISCUSSION}

The results of adult immersion test using the ethanolic extracts of leaves of P. glabra and G. sepium are shown in Table 1 and 2. The efficacy of the extracts against adult female $R$. (B.) annulatus was assessed by measuring the per cent adult mortality, inhibition of fecundity and hatching rate.

Ethanolic extract of leaves of $P$. glabra produced adult tick mortality ranging from 4-16 per cent and inhibition of fecundity $4-15$ per cent. Adult tick mortality was very low even at higher concentrations $(80-100 \mathrm{mg} / \mathrm{mL})$ tested. Ethanolic extract of P. glabra $(50-100 \mathrm{mg} / \mathrm{mL})$ considerably blocked the hatchability of the eggs in comparison to the control. 
Table 1: Effect of ethanolic extract of leaves of $P$. glabra against $R$. (B.) annulatus

\begin{tabular}{llllllll}
$\begin{array}{l}\text { S } \\
\text { No. }\end{array}$ & Acaricide & $\begin{array}{l}\text { Mean ticks weight } \\
\text { per replicate } \pm \\
\text { SEM }\end{array}$ & $\begin{array}{l}\text { Mean \% adult } \\
\text { mortality within } \\
\text { 15 days } \pm \text { SEM }\end{array}$ & $\begin{array}{l}\text { Mean egg mass } \\
\text { per replicate } \pm \\
\text { SEM }\end{array}$ & $\begin{array}{l}\text { Index of } \\
\text { fecundity } \pm \\
\text { SEM }\end{array}$ & $\begin{array}{l}\text { Percentage } \\
\text { inhibition of } \\
\text { fecundity (\%) }\end{array}$ & $\begin{array}{l}\text { Hatching \% } \\
\text { (visual) }\end{array}$ \\
\hline 1 & $\begin{array}{l}0.1 \% \text { tween20 } \\
(\text { control) }\end{array}$ & $0.8993 \pm 0.018^{\mathrm{a}}$ & $0 \pm 0^{\mathrm{a}}$ & $0.4923 \pm 0.028^{\mathrm{a}}$ & $0.5478 \pm 0.031^{\mathrm{a}}$ & 0 & \\
\hline 2 & $50 \mathrm{mg} / \mathrm{mL}$ & $0.8890 \pm 0.051^{\mathrm{a}}$ & $0 \pm 0^{\mathrm{a}}$ & $0.4353 \pm 0.047^{\mathrm{a}}$ & $0.4862 \pm 0.028^{\mathrm{a}}$ & 11.24 & 50 \\
\hline 3 & $60 \mathrm{mg} / \mathrm{mL}$ & $0.9430 \pm 0.043^{\mathrm{a}}$ & $0 \pm 0^{\mathrm{a}}$ & $0.4383 \pm 0.039^{\mathrm{a}}$ & $0.4620 \pm 0.021^{\mathrm{a}}$ & 15.66 & 50 \\
\hline 4 & $70 \mathrm{mg} / \mathrm{mL}$ & $0.9073 \pm 0.006^{\mathrm{a}}$ & $0 \pm 0^{\mathrm{a}}$ & $0.4757 \pm 0.007^{\mathrm{a}}$ & $0.5243 \pm 0.005^{\mathrm{a}}$ & 4.29 & 50 \\
\hline 5 & $80 \mathrm{mg} / \mathrm{mL}$ & $0.9643 \pm 0.030^{\mathrm{a}}$ & $4.165 \pm 4.165^{\mathrm{ab}}$ & $0.4588 \pm 0.026^{\mathrm{a}}$ & $0.4751 \pm 0.017^{\mathrm{a}}$ & 13.27 & 50 \\
\hline 6 & $90 \mathrm{mg} / \mathrm{mL}$ & $0.9703 \pm 0.047^{\mathrm{a}}$ & $8.33 \pm 8.3^{\mathrm{ab}}$ & $0.4580 \pm 0.036^{\mathrm{a}}$ & $0.4779 \pm 0.050^{\mathrm{a}}$ & 12.76 & 50 \\
7 & $100 \mathrm{mg} / \mathrm{mL}$ & $0.9325 \pm 0.023^{\mathrm{a}}$ & $16.66 \pm 6.80^{\mathrm{b}}$ & $0.4438 \pm 0.026^{\mathrm{a}}$ & $0.4747 \pm 0.018^{\mathrm{a}}$ & 13.34 & 50
\end{tabular}

n: 4; Values are Mean \pm SEM, a,b $(\mathbf{P}<\mathbf{0 . 0 5})$ : significant difference when compared with the control

Table 2: Effect of ethanolic extract of leaves of $G$. sepium against $R$. (B.) annulatus

\begin{tabular}{llllllll}
$\begin{array}{l}\text { S } \\
\text { No. }\end{array}$ & Acaricide & $\begin{array}{l}\text { Mean ticks weight } \\
\text { per replicate } \pm \\
\text { SEM }\end{array}$ & $\begin{array}{l}\text { Mean \% adult } \\
\text { mortality within } \\
\text { 15 days } \pm \text { SEM }\end{array}$ & $\begin{array}{l}\text { Mean egg mass } \\
\text { per replicate } \pm \\
\text { SEM }\end{array}$ & $\begin{array}{l}\text { Index of } \\
\text { fecundity } \pm \\
\text { SEM }\end{array}$ & $\begin{array}{l}\text { Percentage } \\
\text { inhibition of } \\
\text { fecundity (\%) }\end{array}$ & $\begin{array}{l}\text { Hatching \% } \\
\text { (visual) }\end{array}$ \\
\hline 1 & Water $($ control) $)$ & $0.8663 \pm 0.101^{\mathrm{bc}}$ & $0 \pm 0^{\mathrm{a}}$ & $0.4433 \pm 0.072^{\mathrm{b}}$ & $0.5034 \pm 0.027^{\mathrm{a}}$ & 0 & 100 \\
\hline 2 & $50 \mathrm{mg} / \mathrm{mL}$ & $0.8663 \pm 0.044^{\mathrm{bc}}$ & $0 \pm 0^{\mathrm{a}}$ & $0.4275 \pm 0.021^{\mathrm{b}}$ & $0.4968 \pm 0.021^{\mathrm{a}}$ & 1.31 & 100 \\
\hline 3 & $60 \mathrm{mg} / \mathrm{mL}$ & $0.6053 \pm 0.038^{\mathrm{a}}$ & $4.165 \pm 4.16^{\mathrm{a}}$ & $0.2998 \pm 0.041^{\mathrm{a}}$ & $0.4891 \pm 0.044^{\mathrm{a}}$ & 2.84 & 100 \\
\hline 4 & $70 \mathrm{mg} / \mathrm{mL}$ & $0.7565 \pm 0.034^{\mathrm{b}}$ & $4.165 \pm 4.16^{\mathrm{a}}$ & $0.3593 \pm 0.020^{\mathrm{ab}}$ & $0.4743 \pm 0.006^{\mathrm{a}}$ & 5.78 & 100 \\
\hline 5 & $80 \mathrm{mg} / \mathrm{mL}$ & $0.9040 \pm 0.049^{\mathrm{bc}}$ & $12.49 \pm 7.97^{\mathrm{a}}$ & $0.4220 \pm 0.035^{\mathrm{b}}$ & $0.4649 \pm 0.020^{\mathrm{a}}$ & 7.65 & 100 \\
\hline 6 & $90 \mathrm{mg} / \mathrm{mL}$ & $0.9523 \pm 0.023^{\mathrm{c}}$ & $12.49 \pm 4.16^{\mathrm{a}}$ & $0.4333 \pm 0.009^{\mathrm{b}}$ & $0.4565 \pm 0.020^{\mathrm{a}}$ & 9.32 & 100 \\
\hline 7 & $100 \mathrm{mg} / \mathrm{mL}$ & $0.9455 \pm 0.019^{\mathrm{c}}$ & $12.49 \pm 4.16^{\mathrm{a}}$ & $0.4120 \pm 0.022^{\mathrm{ab}}$ & $0.4349 \pm 0.014^{\mathrm{a}}$ & 13.61 & 100 \\
\hline
\end{tabular}

n: 4; Values are Mean \pm SEM; ${ }^{a, b, c}(\mathbf{P}<\mathbf{0 . 0 5})$ : Significant difference when compared with the control

Ethanolic extract of $G$. sepium also produced adult tick mortality in the range of 4-12 per cent. The inhibition of fecundity was dose dependent ranging from 1.31 to 13.61 per cent. The extract did not affect the hatching of eggs laid by treated females.

The toxic phytochemicals that primarily constitute the secondary metabolites affect the nerve axon and synapses, muscles, respiration and behaviour of the insects (Klocke, 1989). In fact, some of these phytochemicals were used to develop commercial insecticides and could serve as models for new insect control agents (Balandrin et al., 1985).

Phytoconstituents of P. glabra include furanoflavonols, chromenoflavones, flavones, furanodiketones and flavonoid glucosides (Pathak et al., 1983; Ahemed et al., 2004; Yin et al., 2006). Karanjin, $\beta$-sitosterol, pongamol, pongaglabrone, pongapin, kangone, glabrachromene, pongaflavone, pongol, glabrachrome-II and glabrachalcone were previously isolated from seeds of P. glabra. Kaempferol, $\beta$-sitosterol and pongaglabol were isolated from flowers while demethoxy kanugin, pongachromene were isolated from stem bark of the same plant (Nirmal et al., 2007). Furanoflavonoids (pongapinnol A-D, coumestan, pongacoumestan), flavonoids (pongamones A-E), sterols and fattly acids were also reported from P. pinnata (Shameel et al., 1996; Yadav et al., 2004; Li et al., 2006). The phytoconstituents of the $G$. sepium bark and leaves include flavonoids (Manners and Jurd, 1979), triterpenoid saponins (Rastrelli et al., 1999a, b), stigmastanol glucoside (Herath and de-Silva, 2000), rhamnogalactoside of kaempferol (Rangaswami and Iyer, 1966), coumarin, coumaric acid and melilotic acid (Griffiths, 1962).

Both extracts tested in the present study were previously reported for their larvicidal effects against mosquitoe vectors (Shanmugasundaram et al., 2008; Sharma et al., 1998). Deltamethrin, the common synthetic pyrethoid compound used in field conditions for cattle tick control, produced a mean adult mortality of $16.662 \pm 6.803$, inhibition of fecundity of 57.3 per cent and hatching of $0-10$ per cent (Sunil et al., 2013; Divya et al., 2014) at 30 ppm concentration. Similarly, cypermethrin at $200 \mathrm{ppm}$ concentration also caused mortality of 45.83 per cent and inhibition of fecundity of 86.99 per cent, while the drug did not affect hatching of ova laid by treated ticks (Ravindran et al., 2014).

In the present study, the crude ethanolic extracts of the leaves of the P. glabra and G. sepium did not cause considerable adult mortality or inhibition of egg laying capacity of the treated ticks. The extract significantly inhibited the hatching of the laid ova by treated ticks. Our observation 
is contrary to that of Bisen et al. (2011) who revealed that the leaf extract of $P$. glabra produced a 66.67 per cent efficacy against $R$. (B.) microplus. However, seed oil of P. glabra was widely reported as acaricidal agent especially against mites (Chhabra et al., 1994; Das and Sreekrishanan, 1998; Kale and Panchegaonkar, 1969; Prajapatie and Hiregoudar, 1976; Ravindran and Subramanian, 2000, 2002). Inhibition of fecundity of karanj oil against $R$. (B.) microplus was previously recorded (Bisen et al., 2011).

Leaf extract of G. sepium was reported as acaricidal against plant mite Tetranychus cinnabarinus (Sivira et al., 2011) and demodicosis in $\operatorname{dogs}$ (Viste et al., 2013). Moreover, the plant extract revealed activity against Rhipicephalus (Boophilus) microplus (Rodriguez and Pulido, 2015) also. However, in the present study we could not observe any acaricidal effects for this extract. We presume that the insect repellant activity of G. sepium leaves when used freshly as paste may be due to the highly volatile compounds present in it which might have lost during shade drying and ethanolic extraction.

In the present study, it was observed that ethanolic extract of leaves of P. glabra significantly inhibited the hatching of the laid ova by treated ticks. Previously, similar hatching blocking effect was observed with two other extracts viz., Leucas aspera (Ravindran et al., 2011) and Jatropha curcas (Juliet et al., 2012). However, the phytochemicals responsible for this activity could not be ascertained.

\section{CONCLUSION}

Ethanolic extract of the leaves of Gliricidia sepium did not reveal any acaricidal effect useful for control of Rhipicephalus (Boophilus) annulatus. However, ethanolic extract of the leaves of $P$. glabra significantly inhibited the hatching of the laid ova by treated ticks.

\section{CONFLICT OF INTEREST}

The authors declare that there is no conflict of interest regarding the publication of this research paper.

\section{ACKNOWLEDGEMENTS}

Financial supports from Indian Council of Agricultural Research (NAIP/Comp-4/C2066/2007-08, NFBSFARA/ BSA-4004/2013-14, 7(2)/2011 EPD) and Kerala State Council of Science and Technology and Environment (020/SRSAGR/2006/CSTE，010-14/SARD/13/CSTE) are thankfully acknowledged.

\section{AUTHORS' CONTRIBUTIONS}

All authors contributed equally.

\section{REFERENCES}

-Adama K, Amadou T,Man N, Isidore GB., Valentin B, Hamidou $\mathrm{T}$ H, Gaston BMAM (2012). In vitro anthelmintic activity of Leuceana leucocephala (Lam.) De Wit. (Mimosaceae) and Gliricidia sepium (Jacq.) Kunth ex Steud (Fabaceae) leave extracts on Haemonchus contortus ova and larvae. J. Chem. Pharm. Res. 4: 303-309.

- Ahemed G, Yadav PP, Maurya R (2004). Furano flavonoid glycosides from Pongamia pinnata fruits. Phytochem. 65: 921-924. https://doi.org/10.1016/j.phytochem.2004.01.020

-Arulvasu S, Suppriya SV, Babu G (2012). Anticancer activity of the P. glabra $V$. seed oil extract against selected human cancer cell lines. Int. Res. J. Pharm. 3: 131-134.

-Balandrin MF, Klocke JA, Wurtele ES, Bollinger WH (1985). Natural plant chemicals; sources of industrial and medicinal materials. Science. 228: 1154-1160. https://doi.org/10.1126/ science. 3890182

-Bisen S, Mandal, SC, Sanyal PK, Pal S, Ghosh RC, Singh M (2011). Effect of some phytotherapeutic agents on egg production of Rhipicephalus (Boophilus) microplus. Indian J. Anim. Res. 45: 289 - 294.

-Biswal B, Saha D, Jena A, Jana SB, Koley A, Sur D, Mohanty JC (2011). Anti-bacterial activity of leaf extract of Derris indica. Int. J. Res. Pharm. Biomed. Sci. 2: 271-273.

-Brijesh S, Daswani PG, Tetali P, Rojatkar SR, Anita NH, Birdi TI (2006). Studies on Pongamia pinnata (L) Pierre leaves: Understanding the mechanism(s) of action in infectious diarrhea. J. Zhejiang Univ. Sci. B. 7: 665-674. https://doi. org/10.1631/jzus.2006.B0665

- Chhabra MB, Rajindar K, Gupta SK (1994). Efficacy of Dermocept (Herbal) cream against mange in camel and buffalo. Indian Vet. J. 71: 167-169.

- Csurhes S, Edwards R (1998). Potential environmental weeds in Australia; candidate species for preventative control. Queens Land Department of Natural Resources; Land Protection, Locked Bag 40, Coorparoo Delivery Centre Old 4151. Pp. 164.

-Das SS, Sreekrishnan R (1998). Therapeutic efficacy of AV/ EPP/14 herbal ectoparasiticide against sarcoptic mange infestation in rabbits. J. Vet. Parasitol. 12: 135-136.

-Dipeolu OO, Ndungu JN (1991). Acaricidal activity of "Kupetaba" a ground mixture of natural products against Boophilus microplus. Vet. Parasitol. 38: 327-338. https://doi. org/10.1016/0304-4017(91)90144-K

-Divya TM, Soorya VC, Amithamol KK, Juliet S, Ravindran R, Nair SN, Ajithkumar KG (2014). Acaricidal activity of alkaloid fractions of Leucas indica Spreng against Rhipicephalus (Boophilus) annulatus tick. Trop. Biomed. 31: 46-53.

-Drummond RO, Ernst SE, Trevino JL, Gladney WJ, Graham $\mathrm{OH}$ (1973). Boophilus annulatus and Boophilus microplus laboratory tests for insecticides. J. Econ. Entomol. 66: 130133. https://doi.org/10.1093/jee/66.1.130

-FAO (2004). Guidelines for resistance management and integrated parasite control in ruminants. Rome: Food and Agriculture Organization of the United Nation.

- Ganesh M, Vasudevan M, Kamalakannan K, Kumar AS, Vinoba M, Ganguly S, Sivakumar T (2008). Anti-inflammatory and analgesic effects of Pongamia glabra leaf gall extract. Pharmacol. Online. 1: 497-512.

-Griffiths LA (1962). On the co-occurrence of coumarin, o-coumaric acid, and melilotic acid in Gliricidia sepium 
and Dipteryx odorata. J. Exp. Bot. 13: 169-175. https://doi. org/10.1093/jxb/13.2.169

-Herath HMTB, de-Silva S (2000). New components from Gliricidia sepium. Fitoterapia. 71: 722-724. https://doi. org/10.1016/S0367-326X(00)00219-7

-Jagannath MS, Muraleedharan K, Hiregoudar LS (1979). Prevalence of ixodid ticks of cattle at Bangalore. Indian J. Anim. Sci. 49: 890-894.

- Jonsson NN, Piper EK (2007). Integrated control programs for ticks on cattle. UQ Printery, Australia. Pp. 135-136.

- Juliet S, Ravindran R, Sunil AR, Kumar KGA, Nair SN, Amithamol KK, Bandyapadhyay A, Rawat AKS, Ghosh S (2012). Jatropha carcass (Linn) leaf extract -a possible alternative for population control of Rhipicephalus (Boophilus) annulatus. Asian Pac. J. Trop. Dis. 2: 225-229. https://doi. org/10.1016/S2222-1808(12)60051-6

- Kale SM, Panchegaonkar MR (1969). Treatment of sarcoptic mange in goats with oil of Karanj. Indian Vet.J. 46: 623-627.

-Klocke JA (1989). Plant compounds as source and models of insect control agents. In: Economics and medicinal plant research (eds. Wagner H, Hikino H, Fransworth HR), Vol. 3, London Academic Press, London. Pp. 103-104. https:// doi.org/10.1016/B978-0-12-730064-1.50009-4

-Koshy TJ, Rajavelu G, Lalitha CM (1982). Ecology and bionomics of boophilids of Tamil Nadu. Cheiron. 11: 25-30.

-Krishnamurthy A (1969). Wealth of India. Publication and Information Directorate, New Delhi, India. Pp. 206.

- Li L, Li X, Shi C, Deng Z, Fu H, Proksch P, Lin W (2006). Pongamone A-E, five flavonoids from the stems of a mangrove plant, Pongamia pinnata. Phytochem. 67: 13471352. https://doi.org/10.1016/j.phytochem.2006.05.016

-Manners GD, Jurd L (1979). Additional flavonoids in Gliricidia sepium.Phytochem.18:1037-1042.https://doi.org/10.1016/ S0031-9422(00)91473-0

- Misra P, Pal NL, Guru PY, Katiyar JC, Tandon JS (1991). Antimalarial activity of traditional plants against erythrocytic stages of Plasmodium berghei. Int. J. Pharm. 29: 19-23. https://doi.org/10.3109/13880209109082843

- Nazli R, Akthar M, Ambreen S, Solangi AH, Sultana N (2008). Insecticidal, nematicidal and antibacterial activities of Gliricidia sepium. Pak. J. Bot. 40: 2625-2629.

- Nirmal SA, Malwadkar G, Laware RB (2007). Anthelmintic activity of Pongamia glabra. Songklanakarin J. Sci. Technol. 29: $755-757$

- Onofree SB, Miniuk CM, deBarros NM, Azevedo JL (2001). Pathogenicity of four strains of entomopathogenic fungi against the bovine tick Boophilus microplus. Am. J. Vet. Res. 62: 1478-1480. https://doi.org/10.2460/ajvr.2001.62.1478

-Pathak VP, Saini TR, Khanna RN (1983). Glabrachalchine from Pongamia glabra seeds. Phytochem. 22: 1303-1304. https://doi.org/10.1016/S0031-9422(00)80118-1; https:// doi.org/10.1016/0031-9422(83)80254-4

- Patel RP, Trivedi BM (1962). Antibacterial activity of seed oil of Pongamia glabra. Indian J. Med. Res. 50: 218-220.

- Prajapati RB, Hiregoudar LS (1976). Treatment of psoroptic mange in buffaloes with mineral and plant oil. Indian Vet. J. 53: 150-151.

- Rajamohanan K (1982). Identification of vector for babesiosis of cattle in Kerala. Proceedings of All India symposium of vectors and vectors and vector borne diseases, Trivandrum, Kerala. Pp. 125-128.

- Rangaswami S, Iyer VS (1966). Chemical examination of the leaves of Gliricidia maculata. Curr. Sci. 14: 364-365.
-Rastrelli L, Berger I, Kubelka W, Caceres A, Tommasi DN, Simone DF (1999a). New 12a- hydroxyrotenoids from Glyricidia sepium bark. J. Nat. Prod. 62: 188-190. https://doi. org/10.1021/np9800021

-Rastreli L, Caceres A, Simone DF, Aquino R (1999b). Studies on the constituents on the Gliricidia sepium leaves and roots: Isolation and structure elucidation of new triterpenoid saponins and aromatic compounds. J. Agric. Food Chem. 47: 1537-1540. https://doi.org/10.1021/jf9808731

- Ravindran R, Subramanian H (2000). Ivermectin, amitraz, diflubenzuron and karanji oil in the treatment of notoedric mange in rabbits. Indian Vet. J. 77: 986-987.

-Ravindran R, Subramanian H (2002). Therapeutic trials on psoroptic mange with ivermectin, ekctodex, dimilin and karanji oil. J. Vet. Anim. Sci. 33:23-26.

-Ravindran R, Juliet S, Sunil AR, Kumar KG A, Nair SN, Amithamol KK, Shynu M, Rawat A KS, Ghosh S (2011). Eclosion blocking effect of ethanolic extract of Leucas aspera (Lamiaceae) on Rhipicephalus (Boophilus) annulatus. Vet. Parasitol. 179: 287-290. https://doi.org/10.1016/j. vetpar.2011.02.021

-Ravindran R, Ajithkumar KG, Suresh NN, Amithamol KK, Sunil AR., Krishna TPA, Chitra N D, Jyothimol G, Ghosh S, Juliet S (2014). Acaricidal effects of fenvalerate and cypermethrin against Rhipicephalus (Boohilus) annulatus. Trop. Biomed. 31: 449-455.

- Rodríguez MCE, Pulido SNJ (2015). Efficacy of plant extracts on the adult tick Rhipicephalus Boophilus) microplus and oviposition. Rev. Cubana Plant Med. 20: 375-388.

-Sunil AR, Amithamol KK, Juliet S, Nair SN, Kumar KGA, Soorya VC, Divya TM, Jyothimol G, Ghosh S, Ravindran R (2013). Acaricidal effect of Cassia fistula Linn. leaf ethanolic extract against Rbipicephalus (Boophilus) annulatus. Trop. Biomed. 30: 231-237.

-Satyavati GV, Gupta AK, Neeraj T (1987). Medicinal plants of India. ICMR, New Delhi, India. Pp. 490.

-Shameel S, Usmanghani K, Ali MS (1996). Chemical constituents from seeds of Pongamia pinnata (L.) Pierre. Pak. J. Pharm. Sci. 9: 11- 20.

-Shanmugasundaram R, Jeyalakshmi T, Dutt MS, Murthy PB (2008). Larvicidal activity of neem and karanja oil cakes against mosquito vectors, Culex quinquefasciatus (Say), Aedes aegypti (L.) and Anopheles stephensi. J. Environ. Biol. 29: 4345.

-Sharma N, Qadry JS, Subramanium B, Verghese T, Rahman SJ, Sharma SK, Jalees S (1998). Larvicidal activity of Gliricidia sepium against mosquito larvae of Anopheles stephansi, Aedes aegypti and Culex quinquefasciatus. Pharm. Biol. 36: 3-7. https://doi.org/10.1076/phbi.36.1.3.4616

-Shoba GF, Thomos M (2001). Study of anti-diarrhoel activity of four medicinal plants in castor oil induced diarrhea. J. Ethnopharmacol. 76: 73-76. https://doi.org/10.1016/ S0378-8741(00)00379-2

-Singh RK, Pandey BL (1996). Anti-inflammatory activity of seeds extracts of Pongamia pinnata in rats. Indian J. Physiol. Pharmacol. 40: 355-358.

-Singh RK, Joshi VK, Goel RK (1996). Pharmacological action of Pongamia pinnata seeds-a preliminary report. Indian J. Exp. Biol. 34: 1204-1207.

-Sivira A, Sanabria ME, Valera N, Vásquez C (2011). Toxicity of ethanolic extracts from Lippia origanoides and Gliricidia sepium to Tetranychus cinnabarinus (Boisduval) (Acari: Tetranychidae) Neotrop. Entomol. 40: 375-379 
- Srinivasan K, Muruganandan S, Lal J, Chandra S, Tandan SK, Prakash VR (2001). Evaluation of anti-inflammatory activity of Pongamia pinnata leaves in rats. J. Ethnopharmacol. 78: 151-157. https://doi.org/10.1016/S0378-8741(01)00333-6

-Subramanian S, Nagarajan S (1988). Wound healing activity of Pongamia glabra. Fitoterapia. 59: 43-44.

-Viste GB, Fontanilla Jr PP, Agpasa VA, Tabije NB, Camalig FM (2013). Efficacy test and acceptability of Kakawate
Advances in Animal and Veterinary Sciences (Gliricidia sepium) leaf extract soap against mange in dogs. Int. Sci. Res. J. 5: 218-226.

-Yadav PP, Ahmad G, Maurya R (2004). Furanoflavonoids from Pongamia pinnata fruits. Phytochem. 65: 439-443. https:// doi.org/10.1016/j.phytochem.2003.09.011

-Yin H, Zhang S, Wu J, Nan H. (2006). Dihydropyranoflavones from Pongamia pinnata. J. Braz. Chem. Soc. 7: 1432-1435. https://doi.org/10.1590/S0103-50532006000700034 